\title{
Paleogenetic Studies in Guajajara Skeletal Remains, Maranhão State, Brazil
}

\author{
Daniela Leite, ${ }^{1}$ Alysson Leitão, ${ }^{1}$ Ana Paula Schaan, ${ }^{1}$ \\ Anderson N. R. Marinho, ${ }^{1}$ Sheila Souza, ${ }^{2}$ Claudia Rodrigues-Carvalho, ${ }^{3}$ \\ Francisca Cardoso, ${ }^{4,5}$ and Ândrea Ribeiro-dos-Santos ${ }^{1}$ \\ ${ }^{1}$ Laboratório de Paleogenética/Laboratório de Genética Humana e Médica, ICB, Cidade Universitária Prof. José da Silveira Netto, \\ UFPA, Rua Augusto Corrêa, 01 Guamá, 66075-970 Belém, PA, Brazil \\ ${ }^{2}$ ENSP/Fiocruz, Avenida Brasil, 4365 Manguinhos, 21040-900 Rio de Janeiro, RJ, Brazil \\ ${ }^{3}$ Museu Nacional/UFRJ, Quinta da Boa Vista, São Cristóvão, 20940-040 Rio de Janeiro, RJ, Brazil \\ ${ }^{4}$ Instituto de Filosofia e Ciências Humanas (IFCH), UFPA, Rua Augusto Corrêa, 01 Guamà, 66075-970 Belèm, PA, Brazil \\ ${ }^{5}$ CRIA, FCSH, Universidade Nova de Lisboa, Campus de Campolide, 1099-085 Lisboa, Portugal
}

Correspondence should be addressed to Ândrea Ribeiro-dos-Santos; akelyufpa@gmail.com

Received 12 November 2013; Revised 3 April 2014; Accepted 9 April 2014; Published 14 May 2014

Academic Editor: Santos Alonso

Copyright (c) 2014 Daniela Leite et al. This is an open access article distributed under the Creative Commons Attribution License, which permits unrestricted use, distribution, and reproduction in any medium, provided the original work is properly cited.

In the early 17th century, French and Portuguese colonizers and Jesuit priests settled in the state of Maranhão and made contact with the Guajajara, an ethnic group that lived along the margins of the Pindaré River. The Guajajara maintained contact with Brazilian national society over the centuries, including with Brazilian admixed populations, and with African slaves that flocked towards the region from the 18th century onwards. The present study investigates the origins of this admixture using mitochondrial genetic variability. The bones of 12 individuals investigated, which are currently part of the collection of the National Museum, were tested for genetic diversity. aDNA was extracted by the phenol-chloroform method and by DNA IQ (Promega, Madison, WI, USA). Amplification of the HVS I region was performed by PCR, followed by direct sequencing using the Big Dye kit (Life Technologies, Foster City, CA, USA). This region was found to represent haplogroups of Amerindians (A, C, and D) and Africans (L, L1b, L1c, and L3). The presence of African haplogroups in Guajajara bones from as early as the 18th century is consistent with historical and anthropological data, suggesting the admixture with Africans and/or Afrodescendants. Therefore, this study demonstrates that women with African haplogroups were introduced into the Guajajara population.

\section{Introduction}

1.1. The Guajajara. Among the indigenous peoples that still inhabit the vast South American continent are the Guajajara, an example of ethnic resistance after four centuries of contact with European, Brazilian, and African populations. The Guajajara are also referred to as the Tenetehara-Guajajara of Maranhão to distinguish them from the Tenetehara-Tembé of Pará, and they belong to the Tupi linguistic family. According to Nimuendaju [1], during the 19th century, the Guajajara lived along the Pindaré, Grajaú, and Mearim rivers (Figure 1), an area that they had occupied since pre-Columbian times according to Wagley and Galvão [2].
A more detailed analysis of the population's demography revealed that although their population size had been severely reduced in the past, it recovered significantly during at least two historical periods and is an extraordinary example of demographic expansion. Another particularity of these groups is their substantial level of admixture [3], both with Africans and Europeans. Additionally, in the contemporary demographic process, it is noticeable that more Guajajara men have married women of the surrounding national society than women have married non-Guajajara men. The greater mobility of men in search of work and the social pressure for the permanence of women within the matrilocal villages help to explain this pattern. According to Wagley and 


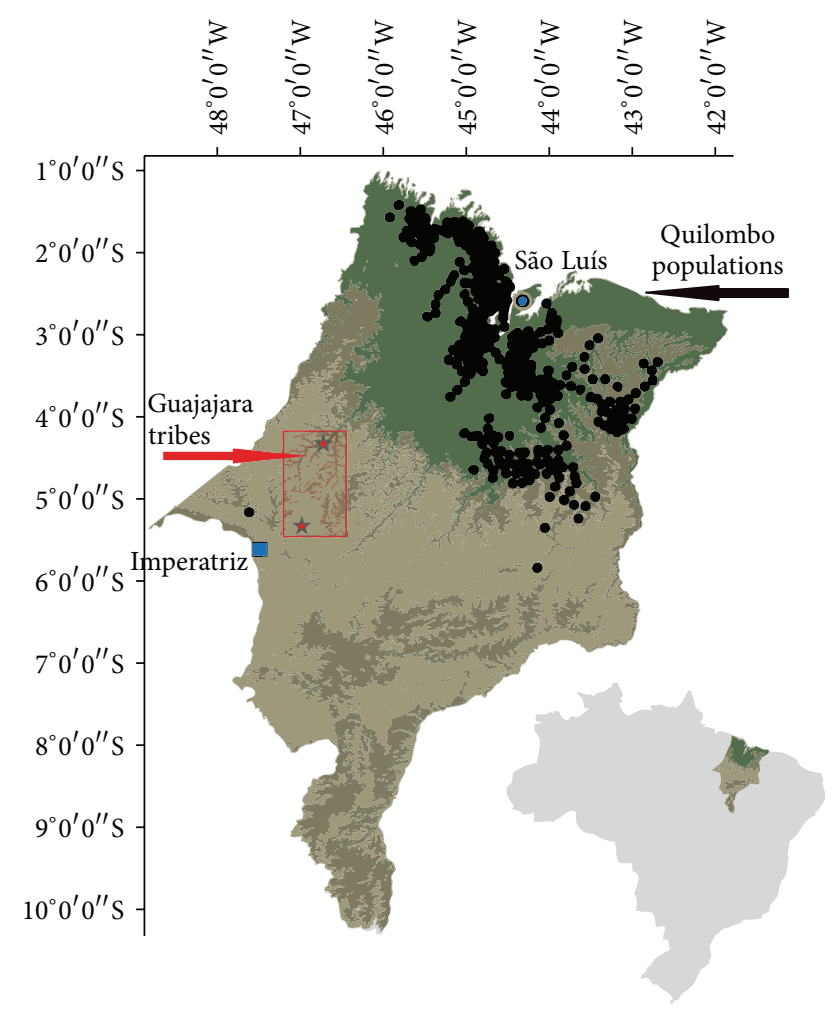

FIgURE 1: Current distribution of the studied Guajajara villages of Kamiranga and Januária (in red) and the quilombola populations (in black) in the state of Maranhão, Brazil (adapted from [59]).

Galvão [2] and Gomes [3], the Guajajara’s traditional kinship system is flexible enough to accommodate the need for seeking marriages in more distant and less related communities, thereby acting as a buffer during the most critical demographic periods. The historical conditions of admixture with other ethnic groups throughout four centuries of contacts are mapped in the historical-anthropological revision by Gomes [3]. However, the precise time that the first events of contact with African and/or Afrodescendants started is not clear in the historical data (Box 1).

1.2. Bioanthropology and Bioarchaeology of Guajajara. The Guajajara are currently one of the most documented ethnic groups of Brazil. Many studies have recorded the ethnography, demography, history, bioanthropology, and bioarchaeology of the Guajajara [4-7]. Lima [4] documented the interesting practice of intentional dental modification prevalent among the Guajajara, and it was confirmed in some exhumed skulls. The dental modification was characterized by symmetric cuts of the lateral and medial angles of the incisors, called "piranha teeth," and was attributed to the adoption of African habits. This interpretation was based on oral information about Afrodescendants from some of the Guajajara in the villages. Other biological features, other than some adopted material culture, music, and customs of these Indians, were also recognized as being of Afro-American origin. In the past, dental modification was found in several regions of Africa. In Brazil, other indigenous groups, such as the Tucuna, Makuxi, Galibi, Karipuna, Pauaxiana, Jauari, and Kaigang, also adopted similar dental modifications for the same reasons since the practice of intentional dental modification has never been demonstrated in Brazilian archeological sites prior to contact $[4,8-10]$. This practice has already been described among Africans and Afrodescendants in Brazil $[9,11,12]$.

The distribution of genetic patterns of the ancestral mtDNA complements and confirms the results obtained by morphological and archeological studies; it has enabled the formulation of a more adequate model to explain prehistoric diversity and the peopling of the Americas. These characteristics confer significant advantages of the use of the mitochondrial genome for the research in the present study. However, one must not forget a significant limitation: from a biological perspective, it only narrates one part of human history, that of the maternal lineage.

The specificity of mtDNA lineages among different populations and groups has favored their use as ancestry markers over the past few decades [13-20]. Among Amerindian populations, five main haplogroups are prevalent $(\mathrm{A}, \mathrm{B}, \mathrm{C}$, $\mathrm{D}$, and $\mathrm{X}-[21,22])[13,23-27]$. Asian populations share American haplogroups (A, B, C, and D), as well as other haplogroups (M, N, G, F, Z, Y, and R) that are described as specific to the Asian continent $[28,29]$. European and EuroAsian populations also possess more frequent haplogroups (I, J, K, H, T, U, V, and W) [15, 28, 29]. In contrast, African populations have a large amount of exclusive haplogroups and subhaplogroups (L0, L1, L2, L3, L4, L5, and L6) [18, 30, 31].

This study is a first step toward elucidating the genetic characteristics of the Guajajara individuals. Our objective is to characterize the admixture with non-Amerindian populations. In addition to contributing to our understanding of the history of this ethnic group, this study aims to corroborate previous bioanthropological studies and to contribute to the knowledge of regional population dynamics during the centuries that followed colonization until the final formation of what is today the Brazilian national society. The present study uses skeletal samples from the Guajajara cemeteries to investigate aDNA mitochondrial haplogroups and to contribute to the reconstruction of part of its history.

\section{Materials and Methods}

2.1. Subjects. The bone samples belong to the Biological Anthropology collection of the National Museum, Rio de Janeiro. The samples were obtained from 12 different individuals exhumed from cemeteries of the Guajajara villages of Januária and Kamiranga (Figure 1). These skeletons are part of the collection brought by Pedro Lima and his collaborators in 1945.

The bone samples were collected from ribs removed from each individual. The ribs were selected following criteria of integrity, absence of pathological signs, anomalies, or severe taphonomic changes that could compromise future investigations about the health state of other parts of the skeletons (bioarchaeological studies, such as age and sex assessment or 
First colonization try at Maranhão

French invade São Luiz island, they contact "Pinariens" (Maranhão)

Portuguese expel the French

Portuguese refer the Guajajara Amerindians (Maranhão)

Jesuits fund the first cathechist missions (Maranhão)

Ships bringing the first Africans slaves, São Marcos bay (Maranhão)

Foundation Mission Carará (Maranhão)

First slave ships officers arrive (Maranhão)

Refuge of Cabanagem soldiers (Grão-Pará)

Foundation of the original village, Januária (Maranhão)

Migration of refugees from drought in the Northeast

Foundation of the Quilombos in Imperatriz (Marnhão)

Foundation of the present village, Januária

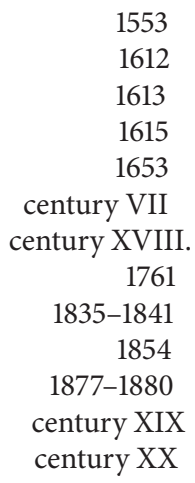

Box 1: Chronology related to contact with the Guajajara (upper Pindaré River).

TABLE 1: Sex, age, and village of origin of the studied samples and a description of analyses performed in each methodological stage.

\begin{tabular}{lcccccc}
\hline Sample & Sex & Age & Number of extractions & Number of sequences & Sequences obtained & Village \\
\hline GAJ 700 & Female? & $18 / 20$ & 2 & 21 & 11 & Kamiranga \\
GAJ 701 & Female? & $20 / 25$ & 2 & 17 & Kamiranga \\
GAJ 709 & Female & +50 & 2 & 21 & 6 & Januária \\
GAJ 713 & Undetermined & $6 / 12$ & 2 & 13 & 6 & Januária \\
GAJ 715 & Female & +20 & 2 & 21 & 10 & Januária \\
GAJ 717 & Male? & $20 / 49$ & 2 & 11 & 7 \\
GAJ 718 & Male? & $20 / 34$ & 2 & Januária & Januária \\
\hline
\end{tabular}

${ }^{1}$ Skeleton number GAJ 717-MN-RJ provided a 19th century chronology of $140 \pm 30$ BP (BETA-291714-AMS, C13 corrected). ${ }^{2}$ Skeleton number GAJ 718-MNRJ provided an 18th century chronology of $210 \pm 40$ BP (GEOCHRON MA GX31824-AMS, C13 corrected).

other additional information). The upper ribs, in particular the fourth rib, were preserved as they are used for age assessment and therefore contain additional bioarchaeological data. All of the selected bone samples were photographed and described prior to being sent to the laboratory for analysis.

Osteometric and osteological data, as well as sex and age, were already estimated in previous studies, and the information in the National Museum archives was used for the present study (Table 1). The material was also dated for the purpose of the present investigation; the skeleton number 717-MN-RJ provided a 19th century chronology of $140 \pm$ 30 BP (BETA-291714-AMS, C $_{13}$ corrected), and the skeleton number $718-\mathrm{MN}-\mathrm{RJ}$ provided an 18th century chronology of $210 \pm 40 \mathrm{BP}$ (GEOCHRON MA GX31824-AMS, C 13 corrected).

2.2. Extraction, PCR, and Sequencing. The extraction and treatment of the DNA samples were performed in the Paleogenetic section of the Human and Medical Genetics Laboratory at the Federal University of Pará (UFPA) according to the established protocol $[25,32]$. The DNA was extracted either with the phenol-chloroform method [33] with modifications or with the DNA IQ System kit (Promega, Madison, WI, USA). The method used depended on the state of preservation of the samples. The extracted material was then stored in a freezer until PCR amplification of the hypervariable region I (HVS-I, ranging from 15920 to 16498).
For this purpose, two sets of primers pairs with overlapping regions were selected, which together amplified a 578-bp region $[25,32]$. A negative control containing all necessary components for a reaction except DNA was used in all the stages of the amplification.

The PCR amplification product was sequenced following the method of Sanger et al. [34], with the Big Dye Terminator Cycle Sequence kit, which uses AmpliTaq DNA Polymerase (Life Technologies, Foster City, CA, USA). The direct sequencing of mtDNA was performed in an ABI Prism-3130 genetic analyzer (Life Technologies). These sequences were exported and printed using the Chromas vl.4 software.

All steps from extraction to sequencing were repeated between two and five times. To confirm the results and to assess the reliability of the sequencing, each sample was on average extracted 1.8 times, enlarged by PCR 4.6 times, and sequenced 15.7 times using the two sets of primers in both directions (forward and reverse).

The result of each sample was compared to the mtDNA reference sequence [35] to identify the haplogroups. Comparisons were also made with the sequences of each research participant to discard the possibility of contamination from inside the laboratory.

2.3. Data Analysis. Neighbor-joining (NJ) trees of mtDNA sequences were constructed with MEGA version 5.0 using the Kimura two-parameter distance method and the NJ method of Saitou and Nei [36] bootstrapped with 10,000 replicates. 
In addition, the samples were subjected to the analysis of inconsistent mutations (phantoms) using the Netmat and Network v. 4.1.0.9 programs [37-39], which were also used to assess the quality and reliability of the obtained results.

\section{Results and Discussion}

The total number of analyzed samples generated 73 sequences, 23 of which were excluded either because of contamination or because they did not generate a conclusive result concerning the HVS-I region of the mtDNA. Among the 12 individuals analyzed in the present study, five were excluded by contamination or by inconclusive results (GAJ 699; GAJ 702; GAJ 704; GAJ 705; GAL 711) (Table 1).

To ensure the reliability of the results, we followed the authentication criteria suggested by Cooper and Poinar [40], Gilbert et al. [41], Hofreiter et al. [42], and Pääbo et al. [43], for results obtained in ancient DNA sequencing. They are (1) isolation of the work area: the DNA extraction must be in a separate area from the PCR amplification; (2) there must be negative control samples to detect the presence of contaminants; (3) respect the molecular state of the sample: amplify small fragments, due to the difficulty of amplifying large fragments; (4) reproducibility: extractions and PCRs must be repeated; (5) cloning: to evaluate the presence of contaminants; (6) independent replication of the results in another laboratory; (7) morphological and biochemical preservation of the material: bone structure and biomolecule preservation aspects that relate to the integrity of the DNA (collagen, amino acids, etc.); (8) quantification to assess the quantity of the extracted DNA. Out of these criteria, the only one we did not follow was item number 6 (independent replication of the results in another laboratory).

In the seven samples that allowed sequencing analysis, haplogroups characteristic of Amerindian and African populations was observed. Of the Amerindian individuals, one belonged to haplogroup $\mathrm{A}$, another to haplogroup $\mathrm{C} 1$, and one to haplogroup D. Of the individuals of African origin, one belonged to haplogroup L, two to haplogroup L1 (L1b e L1c), and another to haplogroup L3e (Table 2). None of the individuals studied belonged to Amerindian haplogroup B or to the European haplogroups.

A reticulation was obtained without filter application and can be explained either by the existence of two different ancestries (Amerindian and African) or by the presence of hotspot mutations. This result was confirmed when the same samples were analyzed after application of a hotspot mutation filter (in the Netmat program) as suggested by Bandelt et al. [44], followed by the analysis of the Network program.

In the present study, the samples were aligned and subjected to phylogenetic analyses with other groups of samples from previous mitochondrial studies [24, 25, 4547]. An NJ tree (Figure 2) of this data set gives tenuous support for separation into seven clusters. There is good bootstrap index (10,000 replicates) for the Amerindians and Africans haplogroups. The extended sequence information clarifies the admixture pattern evident in the Guajajara. These results were consistent; the sample GAJ 701 divided the

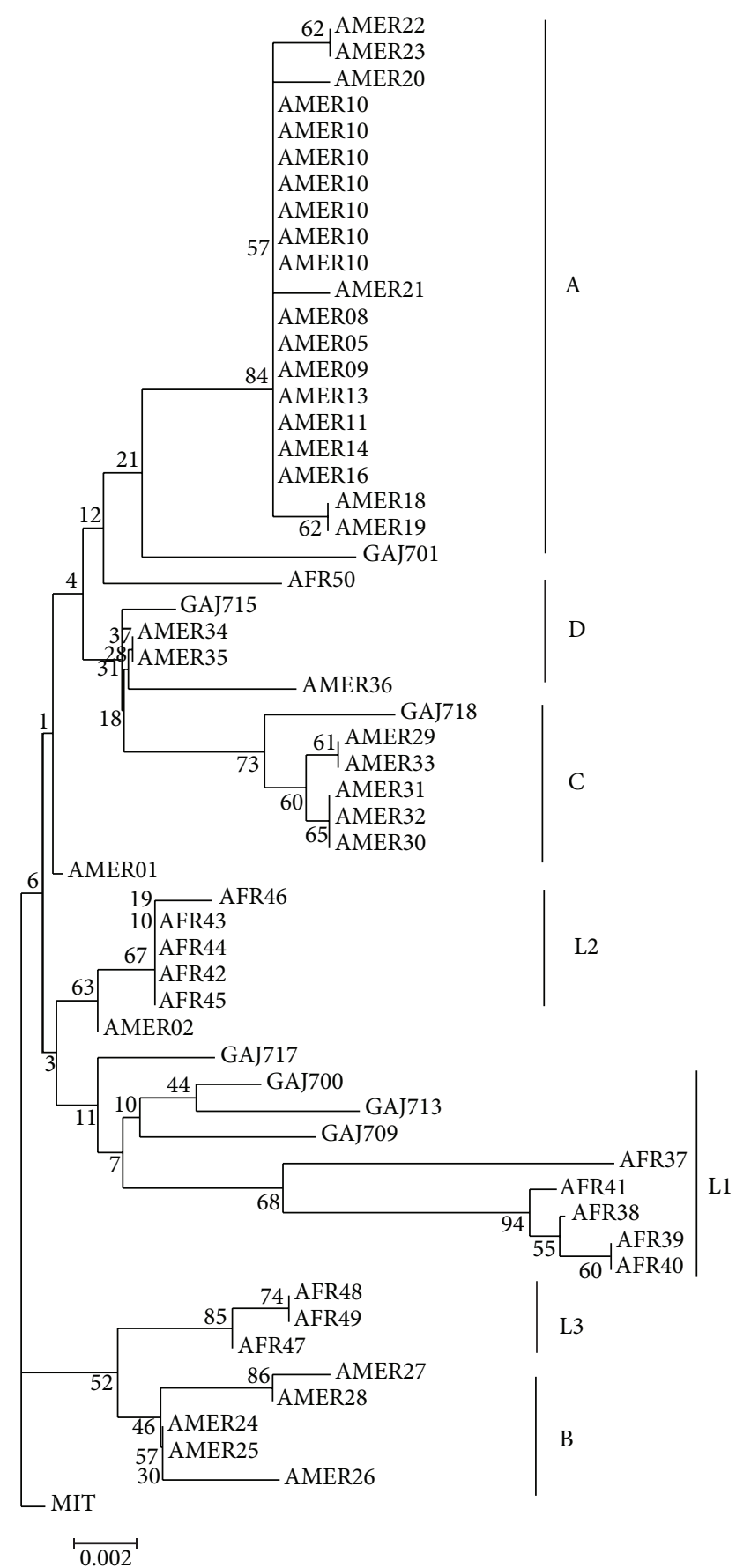

FIGURE 2: NJ Phylotree bootstrapped with 10,000 replicates.

same branch with contemporaneous Amerindian samples that belong to haplogroup A; the samples GAJ 715 and GAJ 718 cluster with Amerindian samples according to their respective haplogroups $\mathrm{D}$ and $\mathrm{Cl}$; and the samples GAJ 700, GAJ 709, GAJ 713, and GAJ 717 cluster with African samples, according to their respective haplogroups L, L3e, L1c, and L1b.

The absence of Amerindian haplogroup B in this series is probably due to the reduced number of examined specimens [13, 24, 27, 48]. However, it may also reflect the underrepresentation of this haplogroup in the formation 
TABLE 2: Mutations assessed in the present study according to their nucleotide position, their haplogroup, and their respective intentional dental modification (IDM).

\begin{tabular}{|c|c|c|c|c|c|c|c|c|c|c|c|c|c|c|c|c|c|c|}
\hline \multirow{6}{*}{ Sample } & \multicolumn{18}{|c|}{ Nucleotide position in the mitochondrial genome } \\
\hline & \multirow{5}{*}{$\mathrm{IDM}^{* * *}$} & 1 & 1 & 1 & 1 & 1 & 1 & 1 & 1 & 1 & 1 & 1 & 1 & 1 & 1 & 1 & 1 & \multirow{5}{*}{ HAPLOG } \\
\hline & & 6 & 6 & 6 & 6 & 6 & 6 & 6 & 6 & 6 & 6 & 6 & 6 & 6 & 6 & 6 & 6 & \\
\hline & & 0 & 1 & 1 & 1 & 2 & 2 & 2 & 2 & 2 & 2 & 3 & 3 & 3 & 3 & 3 & 3 & \\
\hline & & 5 & 0 & 2 & 8 & 2 & 5 & 7 & 9 & 9 & 9 & 1 & 2 & 2 & 2 & 3 & 6 & \\
\hline & & 1 & 4 & 6 & 4 & 3 & 7 & 8 & 0 & 4 & 8 & 1 & 0 & 5 & 7 & 4 & 2 & \\
\hline Sequence reference ${ }^{*}$ & - & A & $\mathrm{C}$ & $\mathrm{T}$ & C & $\mathrm{C}$ & $\mathrm{C}$ & $\mathrm{C}$ & $\mathrm{C}$ & $\mathrm{C}$ & $\mathrm{T}$ & $\mathrm{T}$ & $\mathrm{C}$ & $\mathrm{T}$ & $\mathrm{C}$ & $\mathrm{T}$ & $\mathrm{T}$ & $\mathrm{H}$ \\
\hline GAJ 700 & Present & G & - & - & - & - & $\mathrm{T}$ & - & - & - & - & $\mathrm{C}$ & - & - & - & - & - & $\mathrm{L}$ \\
\hline GAJ 701 & Present & G & - & - & $\mathrm{T}$ & - & - & $\mathrm{T}$ & $\mathrm{T}$ & - & - & - & - & - & - & - & $\mathrm{C}$ & A \\
\hline GAJ 709 & Absent & G & - & - & $\mathrm{T}$ & $\mathrm{T}$ & - & $\mathrm{T}$ & - & - & - & $\mathrm{C}$ & $\mathrm{T}$ & - & - & - & - & L3e \\
\hline GAJ 713 & Absent & - & - & - & - & - & $\mathrm{T}$ & $\mathrm{T}$ & - & $\mathrm{T}$ & - & C & - & - & - & $\mathrm{C}$ & - & Llc \\
\hline GAJ 715 & Undet. & - & - & - & - & - & - & - & - & - & - & - & - & $\mathrm{C}$ & - & - & $\mathrm{C}$ & $\mathrm{D}$ \\
\hline GAJ 717 & Undet. & - & - & $\mathrm{C}$ & - & - & - & $\mathrm{T}$ & - & - & - & $\mathrm{C}$ & - & - & - & - & $\mathrm{C}$ & L1b \\
\hline GAJ 718 & Absent & - & $\mathrm{T}$ & - & - & $\mathrm{T}$ & - & - & - & - & $\mathrm{C}$ & $\mathrm{C}$ & - & $\mathrm{C}$ & $\mathrm{T}$ & - & - & $\mathrm{Cl}$ \\
\hline
\end{tabular}

*Anderson et al. 1981 [35].

${ }^{* * *}$ IDM: Intentional dental modification.

of the community, in particular due to the mechanisms of fission-fusion [49] that rule the population growth of indigenous groups. The absence of haplogroup B in ancestral Amerindian populations is not exclusive to this study $[32,50-$ 53].

In the lineage classified as haplogroup A, five mutations were observed (GAJ 701: 16,051, 16,184, 16,278, 16,290, and 16,362). Only the mutations in bold are consensually accepted as motifs of haplogroup A. The presence of the other mutations can be justified as hotspot positions or private mutations.

Each one of the lineages classified as haplogroups $\mathrm{Cl}$ and D was observed in a single sample and presented six and two mutations, respectively (GAJ 718: 16,104, 16,223, 16,298, $16,311, \mathbf{1 6 , 3 2 5}$, and 16,327; GAJ 715: 16,325, and 16,362). Of these, only the mutations in bold are accepted as motifs of haplogroups $\mathrm{Cl}$ and $\mathrm{D}$.

Each of the lineages classified as haplogroups L, L1b, L1c, and L3e was represented by a single sample and presented three, four, five, and six mutations, respectively (GAJ 700: 16,051, 16,257, and 16,311; GAJ 717: 16,126, 16,278, 16,311, and 16,362; GAJ 713: 16,257, 16,278, 16,294, 16,311, and 16,334; GAJ 709: 16,051, 16,184, 16,223, 16,278, 16,311, and 16,320). Of these, only the mutations in bold are consensually accepted as haplogroup motifs. In order to assign the haplogroups, scientific articles $[24,25,45,46,54-56]$ and databases specialized in mtDNA analysis HaploGrep (http://haplogrep.uibk.ac.at/) and Phylotree (http://www.phylotree.org/) were used.

Analysis of mitochondrial DNA extracted from Guajajara ribs revealed African haplogroups in higher proportion (57.14\%) than indigenous haplogroups. Although the number of successful extractions was low, this result raises an important issue to be confirmed in future studies. The possible penetration of African haplogroups among the Guajajara Indians suggests that women of African ancestry have been incorporated into the Native American group and have reproduced. One cultural marker from the same period as the samples from this study is the intentional dental modification, which has never been recorded as an original practice of the groups of the Tupi linguistic family in Brazil and which was still present among the Guajajara in the middle of the 20th century [4].

During the period when the Guajajara bones from this study originated, historical documents report a decrease in contact with Europeans and a strong African and admixed population presence in the Sertão of Maranhão, an area towards the East to where runaway slaves from the agricultural region fled to [57] and mixed with sertanejos and quilombolas who were living in an increasingly Africanized Maranhão. Therefore, it is likely that the social circumstances and interests among African, Afrodescendant, and Indigenous groups resulted in admixture.

As mentioned earlier, the results obtained here are consistent with the data provided by Wagley and Galvão [2], Consiglio [58], Gomes [3], and other authors on the Guajajara and their admixture with Africans. The process of admixture was possibly initiated in the 17th century, and it is important to stress that at least four slave ships arrived in Maranhão between 1630 and 1693, not to mention the ones that may have clandestinely ported on the Maranhão shores. Therefore, contact and occasional admixture with Africans could have started very early and could have been favored by the practice of enslaving Indigenous people, who provided cheaper labor than Africans at the time.

The beginning of the slave trade in Maranhão during the 17th and 18th century brought Africans from the Benin (West Africa) region and more recently from the Central African coast. The presence of Llb, a haplogroup mostly restricted to West Africa $[46,55,56]$, is consistent with our findings, which identified four African individuals, one of which belonging to L1b haplogroup. 
During the colonial period in Brazil, both African and indigenous populations occupied the basis of the social pyramid. These groups were regarded as nothing more than manual laborers in an economy that was rural and slavebased. This social and economic profile could be found throughout Brazil. Slaves and Amerindians shared a common fate, which they both attempted to escape. These shared life experience spontaneously introduced different nonindigenous ethnical elements into the indigenous villages, which was also promoted by the Empire's strategy of mixing different ethnic groups within the colonies. This process also led to the appearance of the quilombos or multiethnic communities formed by Amerindians and Africans $[46,54,57]$, as seen in the present study.

One of the hypotheses explaining admixture is the Africanization of Maranhão villages after the trade activities of the General Company of Grão-Pará and Maranhão (Figure 1). Although reports on the first quilombos of Maranhão date back to the end of the 19th century, there are a number of documents that address the concerns of the Diretório dos indios with the Guajajara, due to their mixture with "deserters and fugitive slaves" [3]. Only two quilombola communities were close to the Alto Pindaré region, Mandi dos Pretos and Buritirama [59], but there are no documents to confirm their contact with Guajajara. The first census performed in the state of Maranhão in the 19th century (1872) measures in 52,48\% (2.749/5.238) the contribution of foreign individuals of African origin (non-Amerindians) (IBGE).

A second wave of contact, which involved admixed Brazilian people, might have occurred in the Pindaré area beginning from the first half of the 19 th century onwards. The Cabanos came from the state of Pará between 1835 and 1841, as well as the northeastern sertanejos who were fleeing from the severe drought in the northeastern region between 1877 and 1880. These new waves of people may have introduced African or people of Afrodescent to the Guajajara and would revitalize villages whose populations were decreasing. The sertanejos had a significant number of women who practiced intentional dental modifications similar to those observed among the Guajajara [11], making the sertanejos women the probable vector of this cultural practice.

Another work suggests the contact between the African and Amerindian populations in Brazil. Gonsalves et al. [60] described an unexpected mitochondrial lineage, traditionally considered Polynesian, among teeth samples obtained from two Amerindian skulls (Botocudos, who lived in the southwest Brazil at XIX century). The authors presented several possible scenarios to explain the admixture process among Polynesian and Amerindian.

Within this context, the African haplogroups found in this sample are of greater interest as they suggest the important role of African or Afrodescendent women who left their mitochondrial evidence. While the common sense constructed around the process of admixture tends to emphasize the role of enslaved men fleeing captivity and introducing themselves into indigenous communities, it is also important to consider other possibilities, such as the role of women. Although less numerous than men in the slave squads, the presence of fugitive women is documented and proven
[57]. Furthermore, the hypothesis of the kidnapping and/or conquest of women should also be considered. Additionally, the current literature on Guajajara demography draws attention to the fact that men had greater mobility while in search of work, and they probably brought back nonindigenous women to the villages for the purpose of marriage. This scenario undermines the stereotype that most of the sex dynamic was between Brazilian men that married indigenous women. It is therefore reasonable to assume that when the Guajajara men returned to their villages after escaping from oppression or captivity, some of them brought along slaves or admixed women with whom they had established a relationship. The chronology of Guajajaras is summarized in Box 1.

\section{Conflict of Interests}

The authors declare no competing interests.

\section{Acknowledgments}

This work was supported by grants from $\mathrm{CNPq}$ (Conselho Nacional de Desenvolvimento Científico e Tecnológico of Brazil), FINEP (Financiadora de Estudos e Projetos), CAPES (Coordenação de Aperfeiçoamento de Pessoal de Nível Superior), UFPA (PROPESP), Universidade Federal do Pará, and FADESP (Fundação de Amparo a Pesquisa). Ândrea Ribeiro-dos-Santos was supported by CNPq/Produtividade. The funders had no role in study design, data collection and analysis, decision to publish, or preparation of the paper.

\section{References}

[1] IBGE, "BRASIL," Ministério do Planejamento, Orçamento e Gestão. Instituto Brasileiro de Geografia e Estatística, 1981, http://www.ibge.gov.br/.

[2] C. Wagley and E. Galvão, The Tenetehara Indians of Brazil. A Culture in Transition, Columbia University Press, New York, NY, USA, 1949.

[3] M. P. Gomes, O Índio na História-O Povo Tenetehara em Busca da Liberdade, Vozes, Rio de Janeiro, Brazil, 2002.

[4] P. E. Lima, "Deformações tegumentares e mutilação dentária entre os índios Tenetehara," Boletim do Museu Nacional, Antropologia, vol. 16, pp. 1-22, 1954.

[5] M. C. M. Alvim and J. C. O. Gomes, "Hiperostose porosa: anemia malárica? Indios guajajara-estudo de caso," in Paleopatologia and Paleoepidemiologia. Estudos Interdisciplinares, A. J. G. Araujo and L. F. Ferreira, Eds., vol. 1 of Série PANORAMA, pp. 141-158, ENSP, Rio de Janeiro, Brazil, 1992.

[6] M. Locks, Hipoplasias Lineares de Esmalte em Índios TeneteharaGuajajara do Estado do Maranhão, Brasil, Monografia de Especialização, ENSP, Rio de Janeiro, Brazil, 1995.

[7] C. Rodrigues, Patologias Dento-Maxilares Em Coleções de Índios Guajajara, Monografia de Especialização, ENSP, Rio de Janeiro, Brazil, 1995.

[8] E. S. Cunha, "Mutilações dentárias no Negro, no Brasil," in Anais da Sexta Jornada Fluminense de Odontologia, pp. 19-26, Rio de Janeiro, Brazil, 1968. 
[9] W. Nesi, "Mutilação dentária em silvículas de Roraima," Arquivos Fluminenses de Odontologia, vol. 1, no. 3, pp. 8-14, 1968.

[10] W. Nesi and V. Queiroz, "Mutilações dentárias," in Anais da Sexta Jornada Fluminense de Odontologia, pp. 67-70, Rio de Janeiro, Brazil, 1968.

[11] L. Netto, Le Muséum National de Rio-de-Janeiro et son Influence sur les Sciences Naturelles au Brésil, Librairie C. Delagrave, Paris, France, 1889.

[12] A. Lyrio, S. M. de Souza, and C. Rodrigues, "Modificações dentárias na primeira catedral do Brasil, Salvador, Bahia," Revista de Antropologia Portuguesa, vol. 18, pp. 119-141, 2001.

[13] A. Torroni, T. G. Schurr, C.-C. Yang et al., "Native American mitochondrial DNA analysis indicates that the Amerind and the Nadene populations were founded by two independent migrations," Genetics, vol. 130, no. 1, pp. 153-162, 1992.

[14] A. Torroni, R. I. Sukernik, T. G. Schurr et al., "mtDNA variation of aboriginal Siberians reveals distinct genetic affinities with Native Americans," The American Journal of Human Genetics, vol. 53, no. 3, pp. 591-608, 1993.

[15] A. Torroni, K. Huoponen, P. Francalacci et al., "Classification of European mtDNAs from an analysis of three European populations," Genetics, vol. 144, no. 4, pp. 1835-1850, 1996.

[16] Y.-S. Chen, A. Torroni, L. Excoffier, A. S. SantachiaraBenerecetti, and D. C. Wallace, "Analysis of mtDNA variation in African populations reveals the most ancient of all human continent-specific haplogroups," The American Journal of Human Genetics, vol. 57, no. 1, pp. 133-149, 1995.

[17] M. Richards, H. Côrte-Real, P. Forster et al., "Paleolithic and neolithic lineages in the European mitochondrial gene pool," The American Journal of Human Genetics, vol. 59, no. 1, pp. 185203, 1996.

[18] E. Watson, P. Forster, M. Richards, and H.-J. Bandelt, "Mitochondrial footprints of human expansions in Africa," The American Journal of Human Genetics, vol. 61, no. 3, pp. 691-704, 1997.

[19] T. Kivisild, M. J. Bamshad, K. Kaldma et al., "Deep common ancestry of Indian and western-Eurasian mitochondrial DNA lineages," Current Biology, vol. 9, no. 22, pp. 1331-1334, 1999.

[20] V. Macaulay, M. Richards, E. Hickey et al., "The emerging tree of west Eurasian mtDNAs: a synthesis of control-region sequences and RFLPs," The American Journal of Human Genetics, vol. 64, no. 1, pp. 232-249, 1999.

[21] D. C. Wallace, K. Garrison, and W. C. Knowler, "Dramatic founder effects in Amerindian mitochondrial DNAs," American Journal of Physical Anthropology, vol. 68, no. 2, pp. 149-155, 1985.

[22] R. H. Ward, B. L. Frazier, K. Dew-Jager, and S. Päbo, "Extensive mitochondrial diversity within a single Amerindian tribe," Proceedings of the National Academy of Sciences of the United States of America, vol. 88, no. 19, pp. 8720-8724, 1991.

[23] S. Horai, R. Kondo, Y. Nakagawa-Hattori, S. Hayashi, S. Sonoda, and K. Tajima, "Peopling of the Americas, founded by four major lineages of mitochondrial DNA," Molecular Biology and Evolution, vol. 10, no. 1, pp. 23-47, 1993.

[24] S. E. B. Santos, A. K. C. Ribeibo-Dos-Santos, D. Meyer, and M. A. Zago, "Multiple founder haplotypes of mitochondrial DNA in Amerindians revealed by RFLP and sequencing," Annals of Human Genetics, vol. 60, no. 4, pp. 305-319, 1996.

[25] A. K. C. Ribeiro-dos-Santos, S. E. B. Santos, A. L. Machado, V. Guapindaia, and M. A. Zago, "Heterogeneity of mitochondrial DNA haplotypes in Pre-Columbian Natives of the Amazon region," American Journal of Physical Anthropology, vol. 101, no. 1, pp. 29-37, 1996.

[26] D. G. Smith, R. S. Malhi, J. Eshleman, J. G. Lorenz, and F. A. Kaestle, "Distribution of mtDNA haplogroup X among Native North Americans," American Journal of Physical Anthropology, vol. 110, no. 3, pp. 271-284, 1999.

[27] M. Moraga, C. M. Santoro, V. G. Standen, P. Carvallo, and F. Rothhammer, "Microevolution in prehistoric Andean populations: chronologic mtDNA variation in the desert valleys of northern Chile," American Journal of Physical Anthropology, vol. 127, no. 2, pp. 170-181, 2005.

[28] P. Forster, R. Harding, A. Torroni, and H.-J. Bandelt, "Origin and evolution of native American mtDNA variation: a reappraisal," The American Journal of Human Genetics, vol. 59, no. 4, pp. 935-945, 1996.

[29] P. Forster, "Ice Ages and the mitochondrial DNA chronology of human dispersals: a review," Philosophical Transactions of the Royal Society B: Biological Sciences, vol. 359, no. 1442, pp. 255264, 2004.

[30] J. C. Rando, F. Pinto, A. M. González et al., "Mitochondrial DNA analysis of Northwest African populations reveals genetic exchanges with European, Near-Eastern, and sub-Saharan populations," Annals of Human Genetics, vol. 62, no. 6, pp. 531-550, 1998.

[31] Y.-S. Chen, A. Olckers, T. G. Schurr, A. M. Kogelnik, K. Huoponen, and D. C. Wallace, "mtDNA variation in the South African Kung and Khwe-and their genetic relationships to other African populations," The American Journal of Human Genetics, vol. 66, no. 4, pp. 1362-1383, 2000.

[32] A. N. D. R. Marinho, N. C. Miranda, V. Braz, Â. K. Ribeirodos-Santos, and S. M. F. M. de Souza, "Paleogenetic and taphonomic analysis of human bones from Moa, Beirada, and Zé Espinho Sambaquis, Rio de Janeiro, Brazil," Memorias do Instituto Oswaldo Cruz, vol. 101, supplement 2, pp. 15-23, 2006.

[33] J. Sambrook, E. F. Fritschi, and T. Maniatis, Molecular Cloning: A Laboratory Manual, Cold Spring Harbor Laboratory Press, New York, NY, USA, 1989.

[34] F. Sanger, S. Nichelen, and A. R. Coulson, "DNA sequencing with chain-terminating inhibitors," Proceedings of the National Academy of Sciences of the United States of America, vol. 74, no. 12, pp. 5463-5468, 1977.

[35] S. Anderson, A. T. Bankier, A. G. Barriel et al., "Sequence and organization of the human mitochondrial genome," Nature, vol. 290, no. 5806, pp. 457-465, 1981.

[36] N. Saitou and M. Nei, “The neighbor-joining method: a new method for reconstructing phylogenetic trees," Molecular Biology and Evolution, vol. 4, no. 4, pp. 406-425, 1987.

[37] H.-J. Bandelt, P. Forster, B. C. Sykes, and M. B. Richards, "Mitochondrial portraits of human populations using median networks," Genetics, vol. 141, no. 2, pp. 743-753, 1995.

[38] H.-J. Bandelt, P. Forster, and A. Röhl, "Median-joining networks for inferring intraspecific phylogenies," Molecular Biology and Evolution, vol. 16, no. 1, pp. 37-48, 1999.

[39] H.-J. Bandelt, V. Macaulay, and M. Richards, "Median networks: speedy construction and greedy reduction, one simulation, and two case studies from human mtDNA," Molecular Phylogenetics and Evolution, vol. 16, no. 1, pp. 8-28, 2000.

[40] A. Cooper and H. N. Poinar, "Ancient DNA: do it right or not at all," Science, vol. 289, no. 5482, p. 1139, 2000.

[41] M. T. P. Gilbert, H.-J. Bandelt, M. Hofreiter, and I. Barnes, "Assessing ancient DNA studies," Trends in Ecology \& Evolution, vol. 20, no. 10, pp. 541-544, 2005. 
[42] M. Hofreiter, D. Serre, H. N. Poinar, M. Kuch, and S. Pääbo, "Ancient DNA," Nature Reviews Genetics, vol. 2, no. 5, pp. 353359, 2001.

[43] S. Pääbo, H. Poinar, D. Serre et al., "Genetic analyses from ancient DNA," Annual Review of Genetics, vol. 38, pp. 645-679, 2004.

[44] H.-J. Bandelt, L. Quintana-Murci, A. Salas, and V. Macaulay, "The fingerprint of phantom mutations in mitochondrial DNA data," The American Journal of Human Genetics, vol. 71, no. 5, pp. 1150-1160, 2002.

[45] A. C. Feio-dos-Santos, B. M. Carvalho, S. E. B. dos Santos, and Â. K. C. Ribeiro-dos-Santos, "Nucleotide variability of HV-I in admixed population of the Brazilian Amazon Region," Forensic Science International, vol. 164, no. 2-3, pp. 276-277, 2006.

[46] B. M. Carvalho, M. C. Bortolini, S. E. B. dos Santos, and Â. K. C. Ribeiro-dos-Santos, "Mitochondrial DNA mapping of social-biological interactions in Brazilian Amazonian Africandescendant populations," Genetics and Molecular Biology, vol. 31, no. 1, pp. 12-22, 2008.

[47] P. Taboada-Echalar, V. Álvarez-Iglesias, T. Heinz et al., “The genetic legacy of the pre-colonial period in contemporary Bolivians," PLoS ONE, vol. 8, no. 3, Article ID e58980, 2013.

[48] J. García-Bour, A. Pérez-Pérez, E. Prats, and D. Turbón, “Molecular approach to the peopling of the Americas by sequencing mtDNA from extinct Fueguians and Patagons," Chungara, vol. 32, no. 2, pp. 265-266, 2000.

[49] J. V. Neel and F. M. Salzano, "Further studies on the Xavante Indians. X. Some hypotheses-generalizations resulting from these studies," The American Journal of Human Genetics, vol. 19, no. 4, pp. 554-574, 1967.

[50] P. K. Rogan and J. J. Salvo, "Molecular genetics of Pre-Columbian South American mummies," UCLA Symposium in Molecular Evolution, vol. 122, pp. 223-234, 1990.

[51] S. Horai, R. Kondo, K. Murayama, S. Hayashi, H. Koike, and N. Nakai, "Phylogenetic affiliation of ancient and contemporary humans inferred from mitochondrial DNA," Philosophical Transactions of the Royal Society B: Biological Sciences, vol. 333, no. 1268, pp. 409-416, 1991.

[52] D. A. Merriwether, F. Rothhammer, and R. E. Ferrell, "Genetic variation in the New World: ancient teeth, bone, and tissue as sources of DNA," Experientia, vol. 50, no. 6, pp. 592-601, 1994.

[53] D. A. Demarchi, G. M. Panzetta-Dutari, S. E. Colantonio, and A. J. Marcellino, "Absence of the 9-bp deletion of mitochondrial DNA in pre-Hispanic inhabitants of Argentina," Human Biology, vol. 73, no. 4, pp. 575-582, 2001.

[54] Â. K. C. Ribeiro-dos-Santos, J. M. Pereira, M. R. F. Lobato, B. M. Carvalho, J. F. Guerreiro, and S. E. B. dos Santos, "Dissimilarities in the process of formation of Curiaú, a semi-isolated AfroBrazilian population of the Amazon region," American Journal of Human Biology, vol. 14, no. 4, pp. 440-447, 2002.

[55] A. Salas, M. Richards, T. de la Fe et al., "The making of the African mtDNA landscape," The American Journal of Human Genetics, vol. 71, no. 5, pp. 1082-1111, 2002.

[56] A. Salas, M. Richards, M.-V. Lareu et al., "The African diaspora: mitochondrial DNA and the Atlantic slave trade," The American Journal of Human Genetics, vol. 74, no. 3, pp. 454-465, 2004.

[57] M. S. Amantino, O Mundo das Feras: Os Moradores do Sertão Oeste de Minas Gerais-Século XVIII, vol. 1, UFRJ/IFCS, Rio de Janeiro, Brazil, 2001.

[58] V. Consiglio, Fontes Missionárias e História Indígena: Um inventário analítico sobre textos jesuíticos nos arquivos romanos referentes à missão em Maranhão e Grão-Pará-séculos XVIIXVIII, USP, São Paulo, Brazil, 1997.

[59] R. S. A. Anjos and A. Cipriano, Quilombolas: Tradições e Cultura da Resistência, Aori Comunicação, São Paulo, Brazil, 2006.

[60] V. F. Gonçalves, J. Stenderup, C. Rodrigues-Carvalho et al., "Identification of Polynesian mtDNA haplogroups in remains of Botocudo Amerindians from Brazil," Proceedings of the National Academy of Sciences of the United States of America, vol. 110, no. 16, pp. 6465-6469, 2013. 

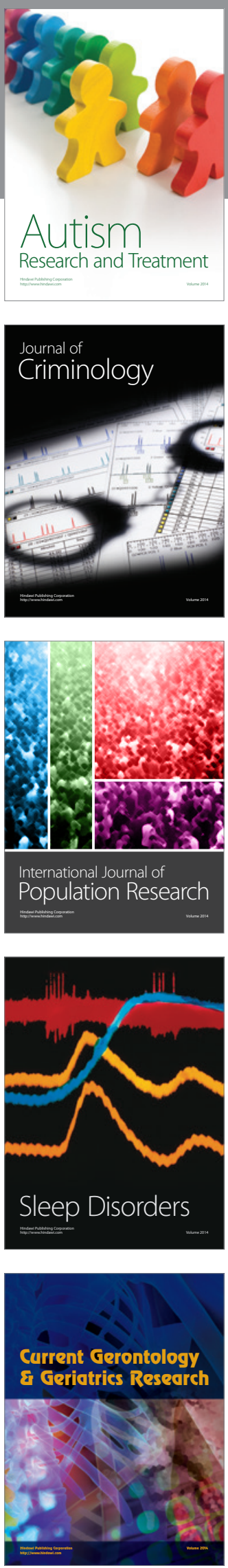
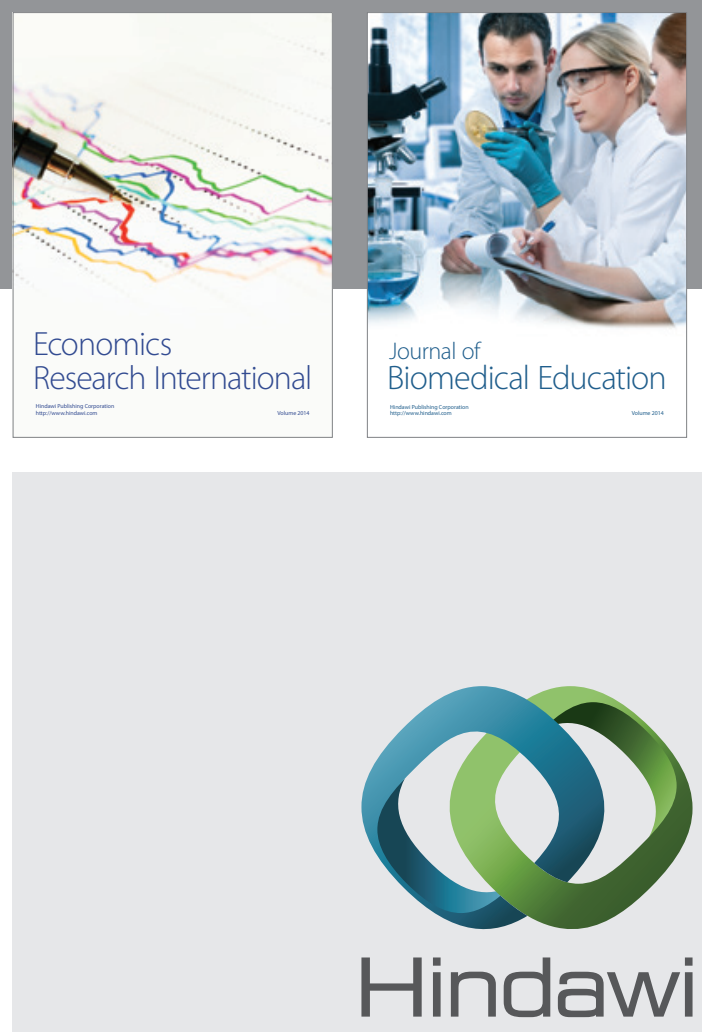

Submit your manuscripts at

http://www.hindawi.com
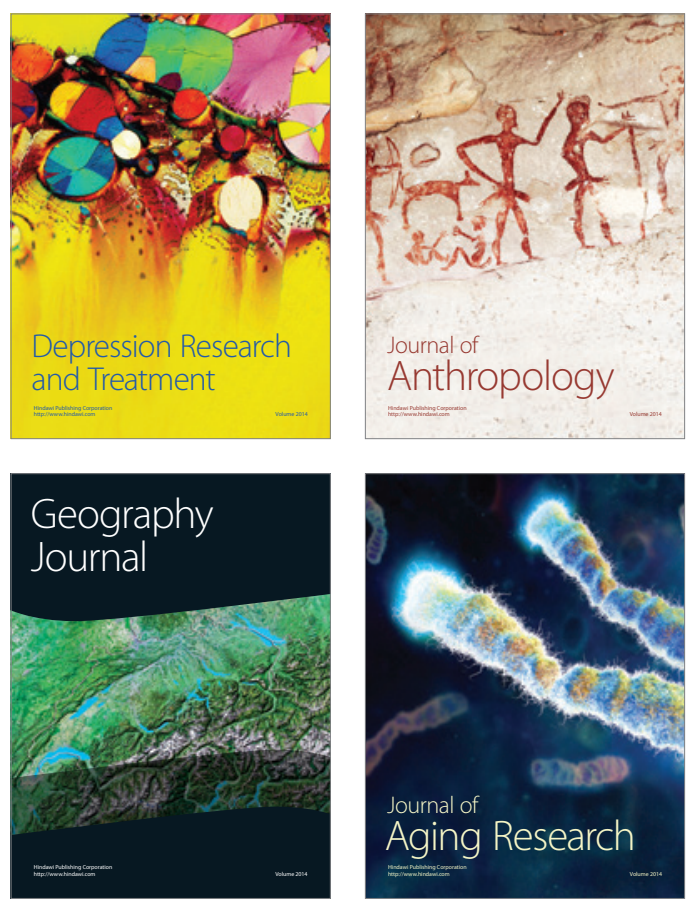
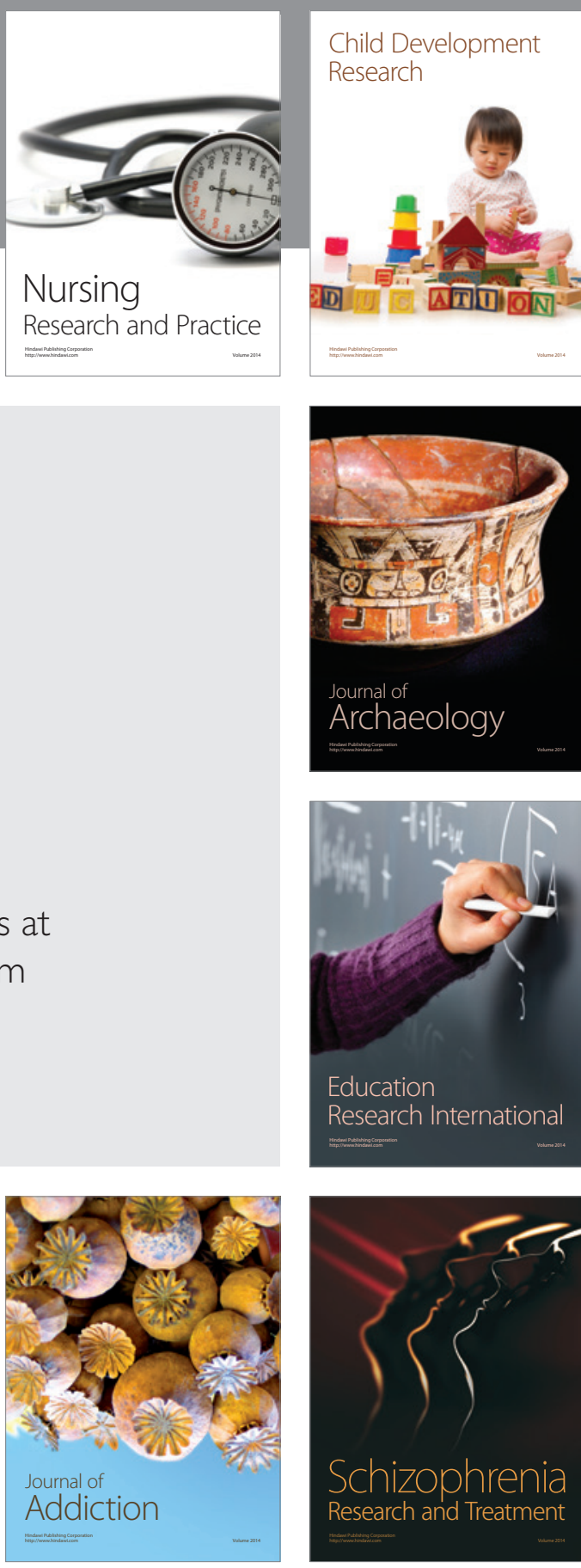

(D)
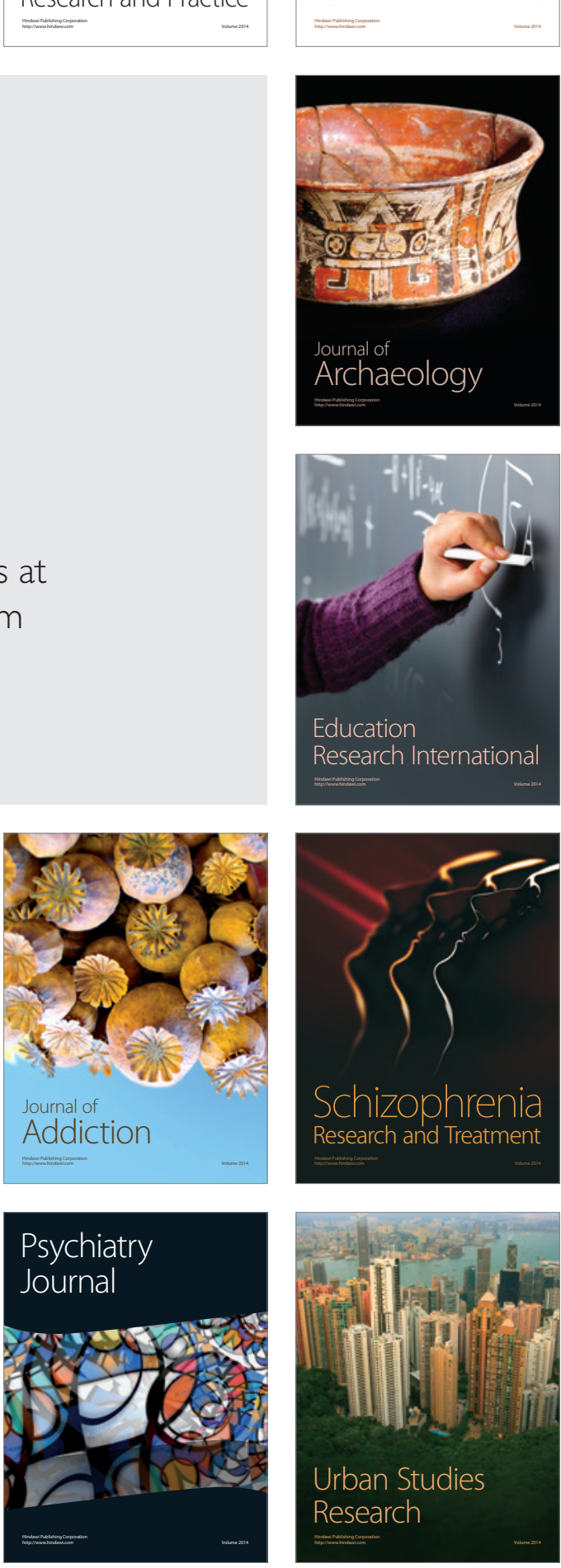